\title{
Word War: A critical discourse analysis of the UN general assembly's annual debate, 2017
}

\author{
Rezvani Sichani, Behnam \\ University of Isfahan, Iran (b.rezvani@fgn.ui.ac.ir) \\ Rezvani, Ehsan \\ Isfahan (Khorasgan) Branch, Islamic Azad University, Iran (rezvani_ehsan_1982@yahoo.com) \\ Moinzadeh, Ahmad \\ University of Isfahan,Iran (moin@fgn.ui.ac.ir)
}

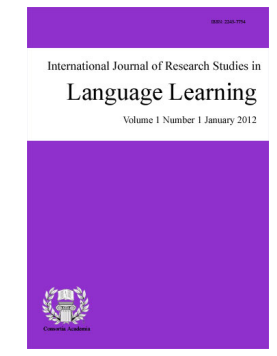

ISSN: 2243-7754 Online ISSN: 2243-7762

OPEN ACCESS

\section{Abstract}

The use of Critical Discourse Analysis (CDA) to unmask ideologies behind words and sentences has become trendy in language studies. The present study seeks to investigate the speeches delivered by two prominent presidents, Hassan Rouhani and Donald Trump, to the United Nations (UN) general assembly, 2017. To do so, Fairclough's (1995, 2013) Model was employed. More specifically, this study focused on the morphological aspect of the two presidents' talks. This being so, the vocabulary section of Fairclough's $(1995,2013)$ Model was utilized as a theoretical framework in this study. The frequency of words was counted and different types of words and their ideological sides were analytically examined. Considering the context of both cases, the linguistic elements of these ideologically bounded talks were described. The results suggest that the two presidents adopted the same linguistics style for their UN persuasive arguments that were adopted in their presidential campaigns and debates. The results also depict that when two political figures hold a set of ideas and values which position them so far from each other, this contrast would lead to marked differences in their discourse too. The findings of this study would be a very a good addition to both language and CDA literature due to the fact that the use of linguistic features in political utterances is as high as ever.

Keywords: Critical Discourse Analysis (CDA); Rouhani; Trump; Fairclough's Model; United Nations 


\section{Word War: A critical discourse analysis of the UN general assembly's annual debate, 2017}

\section{Introduction}

The use of linguistic elements in order to produce dramatic political effects and win the people's hearts is undeniable. Nowadays, there are many linguists who help politicians in the process of making their formal speeches. Given this, Critical Discourse Analysis (CDA) of politicians' speeches soon became a hit topic in linguistics. However, CDA is not limited only to the linguistic elements that are directly associated with politics. It could be employed for the analysis of movies, novels, advertisements and etc. In this research, Norman Fairclough's $(1995,2013)$ Model, as one of the most practical CDA models in the field, is utilized to examine President Trump's and Rouhani's UN utterances.

To get a better insight into the political context of this research, it could be beneficial to review some areas of conflict between the two statesmen. The UN General Assembly, 2017 was quite special. In fact, it could be described as "Word War" probably to form some sort of association with "Cold War". After President Trump's remarks, President Rouhani tried to react and it seemed as if the UN general assembly hosted a political debate program between the United States of America and the Islamic Republic of Iran representatives. The key point of disagreement and discussion was Joint Comprehensive Plan of Action (JCPOA). JCPOA was signed on July 14, 2015 between Iran and G 5+1 i.e. five permanent members of the United Nations Security Council: China, France, Russia, United Kingdom, United States and Germany with an active involvement of European Union (Resolution 2231, 2015). After Donald Trump victory in the US presidential election on November 8, 2016, the future of JCPOA looked bleak for its supporters since Trump promised to rip JCPAO in case of victory in the US 2016 election (Landler \& Sanger, 2017). After his victory, he continued to label JCPOA as "one of the worst and most one-sided transactions the United States has ever entered into" (Remarks by President Trump on Iran Strategy, 2017) and vows to change or decertify this agreement. In his 2017 UN talk, he went even further and branded JCPOA as "an embarrassment to the United States". In contrast, President Hassan Rouhani is known by JCPOA in the world of politics. Consequently, it could be claimed that two presidents have different profiles with regard to their foreign policies. Bearing this political context in mind, two presidents came to the UN general assembly to deliver their speeches and express their ideas.

This opposition of ideas is expected to be manipulated and strengthened through words. This is where CDA becomes the central concern. Linguists try to uncover hidden strategies that are employed by the speakers or writers to support their ideologies. To show how this encounter is reflected in words selection and morphological features, Norman Fairclough's (2013) questions regarding vocabulary are addressed.

\section{Review of Literature}

To find a unified basis for our analysis, it could be beneficial to analytically review the concepts of Critical Discourse Analysis (CDA) and Ideology. A number of studies that were conducted to investigate similar cases will be mentioned too.

\subsection{Critical Discourse Analysis (CDA) and Ideology}

Critical discourse analysis is a contemporary approach to the study of language and discourses in social institutions. Drawing on poststructuralist discourse theory and critical linguistics, it focuses on how social relations, identity, knowledge and power are constructed through written and spoken texts in communities (Luke, 1997, p. 50) 
CDA conceptualizes language as a discourse (Fairclough, 1995) and focus on the role of language as a "form of social practice" (Fairclough, 1995, p. 92). It is believed that CDA concept has its root in Critical Linguistics studies that were first carried out at the University of East Anglia (Fowler, Hodge, Kress, \& Trew, 1979). Norman Fairclough (1995) and Teun Van Dijk (2006) are two prominent academic figures in the filed who proposed two practical models of CDA.

The use of language for political purposes is in the area of Political Discourse (PD) which is a sub-branch of CDA. The distinguishing factor of PD is that it is just limited to political contexts and actors (Al-Faki, 2014) in contrast to CDA which may include the analysis of novels, movies, advertisements and so forth. Politics has been a trendy topic for language scholars in recent years; consequently, there is a rich literature on PD and it still attracts further scientific endeavor. To improve our understanding of PD, a number of such studies will be noted. Sipra and Rashid (2013) conducted a research to analyze Martin Luther King's Speech within a socio-political framework by employing Fairclough's Model. In another study conducted by Wang (2010), Barack Obama's Victory Speech and Inaugural Address are selected for CDA investigation by utilizing Halliday's Systemic Functional Grammar (Halliday, 1971). Wang (2010) showed how Obama used colloquial style to shorten the distance between himself and the audiences. Moreover, Wang (2010) showed that the frequent use of transitive is apparent in Obama's talk to arouse American people's confidence toward him and his administration.

Donald Trump victory in 2016 American Presidential election and given the fact that he has been known as TV personality made the researchers to think of his language within an academic framework. Rachman and Yunianti (2017), Sulistyo and Khristianto (2017), Atolagbe (2017), Mohammadi and Javadi (2017), Cullen (2017) and Mcclay (2017) are only a number of researchers who focused on Trump's talks analysis and it seems there is a lot to come yet. Rachman and Yunianti (2017) used Van Dijk (2008a) CDA thematic theory to examine President Trump's speech. In the article entitled "Political Discourse Analysis on Trump's Ideology" conducted by Sulistyo and Khristianto (2017), Fairclough's Model (1995) is utilized and the results depicted that Trump's emphasis is on expressing dissatisfaction of the Democrats' government's performance especially in political aspect and economic issues. In another study namely "Donald Trump's Alternative Facts Re-shaping National and International Discourses: The Big D. Analysis", Trump's strategy to restructure national and international policies of the US is investigated and how his strategy is generated and reinforced through his discourse is analyzed (Atolagbe, 2017). Mohammadi and Javadi (2017) in their attempt to unmask Trump's ideological motives and their reflection in his language found that his sentences are powerful, persuasive and empathetic. They claimed that Trump "foregrounds the bad jobs of "out-group" by using emphatic words and sentences" (Mohammadi \& Javadi, 2017, p. 10). "The system is rigged: A discursive analysis of Donald Trump and Bernie Sanders" is the title of a study that was carried out by Jessica Cullen (2017). In this study, it is argued that both Trump and Sanders tries to introduce themselves as anti-establishment candidates through their discourse. She builds upon the notion of populism in both Democrat and Republican camps and refers to dehumanizing language of Trump toward Mexicans, African-Americans and others. Moreover, she touches upon Sanders attempt to distance himself from what he calls "the billionaire class" (p. 27). Robert Mcclay (2017) in an another attempt to explore President Trump discourse claims that Donald Trump "has expressed an appalling ideology of racism, paranoia and xenophobia that unfairly and dishonestly draws false connections with immigrants, foreigners, and his political opposition, and the very real problems that Americans face with respect to jobs and crime" (p. 49).

There are also some studies which address Iranian politicians discourse. For instance, Sahragard and Moghadam (2015) analyzed President Rouhani's discourse with a case study of his inaugural speech. They utilized Van Dijk's socio-cognitive Model for their investigation and they claimed that Rouhani tried to reinforce his moderate nature in his discourse. In their view, "He starts a conservative tone and finishes with a reformist one" (p. 250) and he tries to persuade both conservatives (also known as principlists) and reformists camps that they are all on the same boat. The comparative analysis of the US and Iran presidents' speeches particularly in the UN is addressed in Sharififar and Rahimi (2015) and Mazlum and Afshin (2016) articles too. The first one investigates Obama's and Rouhani's speech in the UN on September 2013 based on Halliday's systematic 
functional Model (1971) and the latter analyzes Obama's and Rouhani's speech to the UN general assembly on 2014 by employing Martin and White (2005) appraisal system of meaning. Mazlum and Afshin (2016) argue that both presidents took non-authorial affectual stance in their discourse and tried to invite the audience to accompany them. To sum up, it could be argued that CDA and in a more particular sense PD has been the theme of many studies in recent years. This study aims to examine the way ideology is manipulated and strengthened through discourse in President Trump's and Rouhani's speeches to the UN general assembly, 2017.

\section{Method}

\subsection{Procedure}

In the first step, full transcripts of President Trump's and President Rouhani's speeches to the $72^{\text {nd }}$ session of the UN general assembly 2017, were downloaded from the UN website ("Statement by H.E. Dr. Hassan Rouhani: President of the Islamic Republic of Iran," 2017; "Statement by H.E. Mr. Donald Trump: President of the United States of America," 2017). With regard to President Rouhani's talk, the official English translation which was provided by the UN was used for the analysis. To objectify our CDA analysis as much as possible, the online software provided by the website "WordCounter.net" was employed to recognize the most frequent words and phrases in their speeches that were believed to represent the presidents' focal points of concerns. The obtained results were tabulated in Table 1 and Table 2 for further investigations. In the next step, Fairclough's $(1995,2013)$ Model was employed to analytically examine each president's top 10 words' experiential values since as Fairclough (2013) claims it is "a cue to the way in which the text producers experience of the natural or world is represented" (p. 93). In his view, experiential values have strong associations with beliefs. Then, the points of clear and sharp disagreements between the two were excerpted from both speeches. The mentioned parts could be seen in Table 3. Finally, this paper's findings about the two presidents' linguistic style and their relationship with the previous studies on the discourse of these two political figures were discussed.

\subsection{Fairclough's $(1995,2013)$ CDA Model}

In this study, Fairclough's $(1995,2013)$ Model was utilized to analyze President Rouhani's and Trump's utterances; therefore, initially it could be beneficial to review CDA in Fairclough's view. Fairclough's understanding of CDA is based on three concepts: Language, Ideology and Power. In Fairclough's (1995) view, ideology is a theoretical concept which is derived from capitalist societies theories to address social class difficulties. Norman Fairclough derives his notion of ideology from the thoughts of Antonio Gramsci (1971) and he believes that "ideology is tied to action, and ideologies are judged in terms of their social effects rather than their truth values" (Fairclough, 1995, p. 76). He believes that "ideologies are generated and transformed in actual discursive events" (Mohammadi \& Javadi, 2017, p. 1).

Norman Fairclough (1995) in his book "Critical Discourse Analysis: The Critical Study of Language" provides us with a diagram as follows:

Figure 1. Fairclough CDA Model (Fairclough, 1995, p. 98)

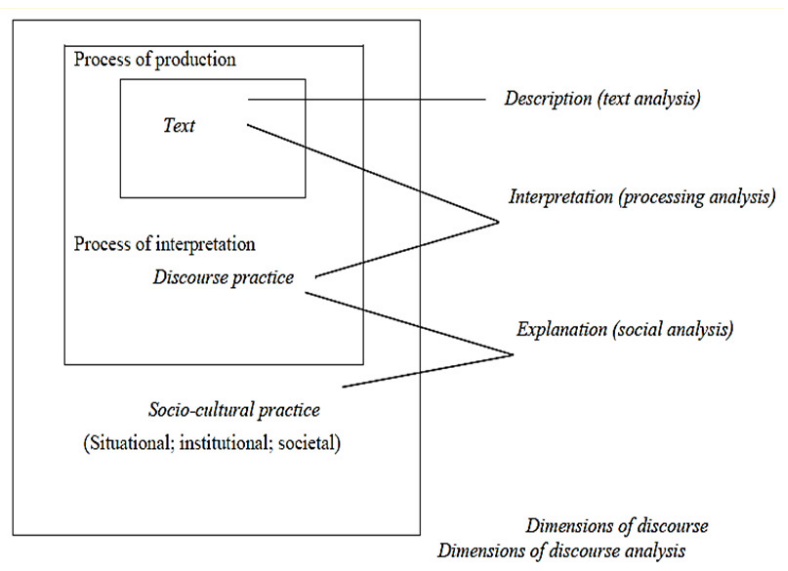


As shown in Fig 1., Fairclough (1995) touches upon three dimensions of discourse: text, discourse practice and socio-cultural practice. The analysis processes of the mentioned three are Description (text analysis), Interpretation (processing analysis) and Explanation (social analysis) respectively. This model is known as a 3D model in the literature too (Sulistyo \& Khristianto, 2017). It could be claimed that Fairclough's (1995) Model is a multilayer process in which the first phase is analyzing text that includes vocabulary, grammar and textual structures. To do so, he provides us with ten questions that could be asked of a text (Fairclough, 2013). As this study is focused on the morphological analysis of President Trump and President Rouhani speeches in the UN, only the first four questions are applicable to our research but the last six questions are mentioned below as well since they are addressed where applicable in a number of cases too.

\section{A. Vocabulary}

1. What experiential values do words have?

What classification schemes are drawn upon?

Are there words which are ideologically contested?

Is there rewording or overwording?

What ideological significant meaning relations (synonymy, hyponymy, antonomy) are there between words?

2. What relational values do words have?

Are there euphemistic expressions?

Are there markedly formal or informal words?

3. What expressive values do words have?

4. What metaphors are used?

B. Grammar

5. What experiential values do grammatical features have?

What types of process and participant dominate?

Is agency unclear?

Are processes what they seem?

Are nominalizations used?

Are sentences active or passive?

Are sentences positive or negative?

6. What relational values do grammatical features have?

What modes (declarative, grammatical question, imperative) are used?

Are there important features of relational modality?

Are the pronouns we and you used, and if so, how?

7. What expressive values do grammatical features have?

Are there important features of expressive modality?

8. How are (simple) sentences linked together?

What logical connectors are used?

Are complex sentences characterized by coordination or subordination?

What means are used for referring inside and outside the text?

\section{Textual structures}

9. What interactional conventions are used?

Are there ways in which one participant controls the turns of others?

What larger-scale structures does the text have? (Fairclough, 2013, pp. 92-93)

This study, due to its topic which focuses on CDA, is descriptive and qualitative in nature. Qualitative study refers to any kind of research that produces findings not arrived by quantification methods (Strauss \& Corbin, 1990). To address the reliability of our analysis, it would be very beneficial to review the concept of reliability in a qualitative research context. The notion of reliability is generally associated with quantitative analysis. In qualitative domain, reliability is the point of many issues and challenges that reflect contradicting ideas (Babaee, 
Le, \& Le, 2013). Stenbacka (2001) simply claims that a qualitative research that generates understanding is reliable. According to Stenbacka (2001), within a qualitative framework reliability is concerned with generating understanding in contrast to a quantitative research that reliability is concerned with purpose of explaining. Moreover, Bashir, Afzal, and Azeem (2008) argue that "the concept of reliability is irrelevant in qualitative research" (p. 39). In another attempt to elaborate on reliability, Guba and Lincoln (1981) claimed that the validity of a qualitative research would be adequate to prove the reliability of that.

Such intense debate would become even livelier when CDA is the case. For instance, Widdowson (2004) holds the view that CDA interpretation, not its analysis, is at the mercy of the researcher. Therefore, Interpretation as a distinguishing feature of discourse analysis poses threat to the notions of validity and reliability considering traditional research practice (Erasga, 2012). Among the mentioned threats by Erasga (2012), the important one is that there is no single and fixed meaning of a text hence interpretation could be challenged. In spite of all the mentioned difficulties, Jørgensen and Phillips (2002) claimed that well-founded arguments not only remain authoritative over time but also they would have their relative concrete applications. Erasga (2012) came up with the same idea and argued that the reliability heavily depends on the force and logic of one's arguments. This being so, a roughly similar method to Khany and Hamzelou (2014) approach in addressing intra and inter reliability of their CDA research was utilized to improve the arguments of this paper. In this study, both speeches were analyzed twice within a month interval and the authors provided their own interpretations separately. Finally, all of the interpretations were collected and only the points of similarities between the scholars' interpretations were mentioned in the discussion to guarantee inter analysis reliability. Furthermore, as this research is a case study, it is limited in scope and the analyzed data is truly representative; thus, potential bias is to some extent minimized in text selection therefore it would substantially contribute to the trustworthiness and reliability of the paper (Sriwimon \& Zilli, 2017).

\section{Findings and discussions}

Although the amount of time which was devoted to the US president was approximately twice as much as the amount of time which was devoted to his Iranian counterpart, it is apparent that Rouhani used less sentences compared to Trump, since the analysis shows that Trump's sentences are short and colloquial. In contrast, Rouhani prefers formal language that sometimes contains long sentences.

As can be seen in Table 1, President Rouhani, who wants to be known as a moderate statesman and diplomat, used words like "peace", "rights" and "moderation" several times. Hassan Rouhani, as the president of Iran who concluded JCPOA with G 5+1, tried to draw the attention to diplomatic relations. It is clear that Rouhani tries to form a strong association between his "moderation" policy and "global peace". Fairclough (2013) provides us with the importance of synonymy, hyponymy and antonomy in CDA. It is worth noting here that this classification is concerned with meaning systems not just meaning words. For instance, it is very clear that in President Rouhani's talk, moderation and peace are used as near synonyms. The frequent use of words like "peace" and "moderation" plays a key role in forming a strong association between them in the minds of the audiences. The following paragraph clearly shows that attempt:

"Excellencies, the call of moderation is from a nation that has been committed to it. We are not preaching it but practicing it. The JCPOA is a case in point. The deal is the outcome of two years of intensive multilateral negotiations overwhelmingly applauded by the international community and endorsed by the Security Council as a part of Resolution 2231. As such, it belongs to the international community in its entirety and not only to one or two countries. The JCPOA can become a new model for global interactions, based on mutual constructive engagement between all of us." 
Word War: A critical discourse analysis of the UN general assembly's annual debate, 2017

Table 1

President Rouhani Top 10 Words

\begin{tabular}{llll|llll}
\hline No. & Word & Frequency & Percentage & No. & Word & Frequency & Percentage \\
\hline 1 & Iran & 16 & $3 \%$ & 6 & rights & 10 & $2 \%$ \\
2 & people & 13 & $2 \%$ & 7 & global & 10 & $2 \%$ \\
3 & only & 11 & $2 \%$ & 8 & through & 9 & $1 \%$ \\
4 & peace & 11 & $2 \%$ & 9 & nations & 8 & $1 \%$ \\
5 & moderation & 10 & $2 \%$ & 10 & years & 8 & $1 \%$ \\
\hline
\end{tabular}

As shown in Table 2, the word "must" is repeated seventeen times in President Trump's speech. According to Sclafani (2018), the distinguishing characteristic of President Trump compared with his opponents is the expression of powerful and decisive statesman. Sclafani (2018) refers to constant interruption of Hillary Clintons and the debate moderators by Trump. Mcclay (2017) mentions the same element in Trump's style. In his view, "With Trump, We are Strong" is an explicit component of Trump's style (p. 22). It could be claimed that Donald Trump wants to show that he is capable of fulfilling his promise "Make America Great Again" through his discourse by using sentence like "We need somebody that can take the brand of the United States and make it great again" (Mcclay, 2017, p. 32). Therefore, it could be claimed that he adopted the same strategy for his UN talk that he used during his presidential campaigns and debates. The use of imperative structures is by far apparent in his talk for instance he used the phrase "we must" eleven times. It could be a legitimate reason for why Trump's comments are considered as controversial and disrespectful by some since it is claimed that English speakers consider imperative sentences less polite than other types and avoid using them (Kallia, 2005; Tsuzuki, Takahashi, Patschek, \& Zhang, 2005).

Nevertheless, the use of such sentences might be intentional as President Trump tried to appear as a powerful president who can take on global challenges to further clarify that he is more serious than his predecessors against those who oppose the US strategies in global affairs. For instance, the use of "regime" to refer to countries which Trump considers them as enemies of the US is by far apparent (15 times) which might be regarded as a hostile stance toward his oppositions. According to Longman Dictionary of Contemporary English, regime means a government that you disapprove of for some reason. Trump used the literal meaning of the word and it clearly shows that he prefers direct and simple linguistic style. Another case in point is the representation of socialism in Trump's speech when he talks about Venezuela. Fairclough (2013) provides us with an example which shows the way meaning systems are employed to create a hyponymy between totalitarianism and communism in a certain ideology. Nonetheless, Trump clearly equals Venezuelan socialism with failure and it is the case when Fairclough (2013) believes that words are directly related to ideologies.

"The problem in Venezuela is not that socialism has been poorly implemented, but that socialism has been faithfully implemented. From the Soviet Union to Cuba to Venezuela, wherever true socialism or communism has been adopted, it has delivered anguish and devastation and failure."

Table 2

President Trump Top 10 Words

\begin{tabular}{llll|llll}
\hline No. & Word & Frequency & Percentage & No. & Word & Frequency & Percentage \\
\hline 1 & nations & 55 & $4 \%$ & 6 & states & 25 & $2 \%$ \\
2 & people & 50 & $4 \%$ & 7 & countries & 17 & $1 \%$ \\
3 & united & 41 & $3 \%$ & 8 & must & 17 & $1 \%$ \\
4 & all & 29 & $2 \%$ & 9 & more & 16 & $1 \%$ \\
5 & world & 28 & $2 \%$ & 10 & regime & 15 & $1 \%$ \\
\hline
\end{tabular}

Donald Trump speech was very hard to take for Iran. As President Rouhani's speech was delivered a day after the US president, he tried to react to Trump's speech and it soon turned to what could be labeled as "Word War". As a result, in Table 3, utterances that are directly used to show the opposition will be illustrated. 
Table 3

"Word War"

\begin{tabular}{ll}
\hline No. & President Trump \\
\hline 1 & We have a policy of principled realism \\
& We live in a time of extraordinary opportunity ... \\
& But each day also brings news of growing dangers \\
& that threaten everything we cherish and value.
\end{tabular}

President Rouhani

\title{
Moderation
}

Moderation seeks neither isolation nor hegemony.

Moderation is freedom and democracy ... is

beauty

Unfortunately, some deprived themselves of this unique opportunity. They have imposed sanctions really against themselves and now they feel betrayed.

2 One that speaks openly of mass murder, vowing We are the same people who rescued the Jews death to America, destruction to Israel and ruin for from Babylonian servitude, opened our arms to many leaders and nations in this room. welcome Armenian Christians in our midst .... I represent the same Iran that has historically assisted the oppressed. Centuries ago we supported the rights of the Jewish people and today we insist on the restoration of the rights of the Palestinian people. Iran is still the same country supporting justice and seeking tranquility.

3 Rogue regimes ... Rogue states .... As President of the United States, I will always put America first. ... The United States will forever be a great friend to the world, and especially to its allies, but we can no longer be taken advantage of or enter into a one-sided deal where the United States gets nothing in return ... The Iran deal was one of the worst and most one-sided transactions the United States has ever entered into. Frankly, that deal is an embarrassment to the United States, and I don't think you've heard the last of it, believe me.

I declare before you that the Islamic Republic of Iran will not be the first country to violate the agreement but it will respond decisively and resolutely to its violation by any party. It will be a great pity if this agreement would be destroyed by rogue newcomers to the world of politics. The world will have lost an opportunity but such behavior will never impede Iran's course of progress and advancement. By violating its international commitments, the new U.S. administration only destroys its own credibility and undermines international confidence in negotiating with it. Not accepting its word or promise.

$4 \quad$ It has just been announced that we will be spending almost 700 billion dollars on our military and defense. Our military will soon be the strongest it has ever been.

We never threaten_anyone but we do not tolerate threats from anyone. Our discourse is one of dignity and respect. It is the policy of my government to continue to steadily enhance the entrepreneurial environment

5 The United States is one out of 193 countries in the United Nations, and yet we pay 22 percent of the entire budget and more. In fact, we pay far more than anybody realizes. The United States bears an unfair cost burden ...

6 In America, we do not seek to impose our way of life on anyone, but rather to let it shine as an example for everyone to watch.

And we are unmoved by threats and intimidation. We believe in dialogue and negotiation based on equal footing and mutual respect.

\begin{abstract}
Iran does not seek to restore its ancient empire, impose its official religion on others, or export its revolution through the force of arms. We are so confident in the depth of our culture, the truth of our face, and tenacity and longevity of our revolution that we will never seek to export any of them in the way neocolonialists do with the heavy boots of soldiers.
\end{abstract}

Table 3 justifies the title that is employed in this paper to label the two presidents' speeches to the seventy-second session of the United Nations general assembly. From the very beginning, the conflict of ideologies (principled realism vs. moderation) is crystal clear. President Trump used the phrases such as "rogue regimes" or "rogue states" in his speech a number of times and "rogue newcomer" is the phrase that is employed by Rouhani to react. Bearing in mind the two states foreign policies, opposition of interests is noticeable. 
President Rouhani talked about the environment too and emphasized that his administration will invest on the entrepreneurial environment. Perhaps Rouhani wanted to call attention to President Trump's decision to withdraw from Paris agreement on climate change since President Trump earlier stated that he wants to renegotiate a fairer deal for the United States (Shear, 2017) and it could be argued that he has adopted a somewhat similar stance on both JCPOA and CO21 and Rouhani tries to strengthen JCPOA and CO21 association. In short, it could be concluded that foreign policy is the most important issue of concern for both states and both presidents tried to formulate a discourse with perssuasive experiential and expressive values.

Pronouns are very influential in critical discourse analysis, particularly in addressing what Teun Van Dijk (2008b) refers to as "emphasize our good things and their bad things" (p. 105). Donald Trump used 373 pronouns in total. He used "we" 93 times, "our" 63 times, "they" 10 times and "their" 57 times. Hassan Rouhani used "we" 37 times, "our" 31 times, "they" 2 times and "their" 3 times. It can be argued that exclusive pronouns were extensively used by Donald Trump in his talk compared with Rouhani. Inclusive pronouns "we" and "our" have been uttered by both presidents due to the fact that such pronouns can shorten the distance between the speaker and the hearer.

\section{Conclusion}

To investigate political talks, both politics and linguistics interpretations are required to unmask the linguistic choices and strategies of politicians. To address the interdisciplinary nature of this study, Fairclough's (1995, 2013) CDA model was employed to examine the United States of America and Islamic Republic of Iran presidents' talks to the seventy-second session of the United Nations general assembly on $19^{\text {th }}$ and $20^{\text {th }}$ September 2017 respectively. This study focused on morphological analysis of two speeches thus vocabulary section of Fairclough (2013) ten-question model was considered as a theoretical framework and used for the investigation.

Rouhani uses formal language compared to Trump's colloquial style. It was shown how Rouhani tried to manifest his diplomatic style in his discourse and how Trump referred to big problems in the world in his view and the cases that are considered as challenges for his administration. He tried to show that he is powerful and capable enough to face those challenges. To sum up, it could be claimed that Donald Trump and Hassan Rouhani both used the same strategy in their speeches that were adopted during their presidential campaigns too. In this regard, this research offers further support to the findings of the previous studies dedicated to the discourse analysis of these two political figures in their presidential campaigns (Sahragard \& Moghadam, 2015; Sclafani, 2018). In addition, this study showed that political figures tend to employ same linguistic style and strategies to get their own ways regardless of whether they compete with domestic or foreign candidates.

It could be claimed that UN 2017 General Debate was marked with Donald Trump and Hassan Rouhani statements. The conflict of interests between the two statesmen was so conspicuous. In another study conducted by Mazlum and Afshin (2016), it is argued that although Obama and Rouhani differ in many ways, they both implemented similar strategies in their UN talks. By contrast, in this study it was shown that Trump and Rouhani used different strategies in forming their discourse too. It may be claimed that Trump's discourse is quite eccentric and his discourse even in US presidential debates and campaigns was the subject of many studies (Atolagbe, 2017; Cullen, 2017; Mcclay, 2017; Mohammadi \& Javadi, 2017; Rachman \& Yunianti, 2017; Sclafani, 2018; Sulistyo \& Khristianto, 2017). However, based on the obtained results another interpretation could be true as well. It could be claimed that when two political figures hold a set of ideas and values which position them so far from each other like the two ends of a continuum, this contrast would lead to marked differences in their discourse too.

\section{References}

Al-Faki, I. M. (2014). Political speeches of some African leaders from linguistic perspective (1981-2013). 
Rezvani Sichani, B., Rezvani, E., \& Moinzadeh, A.

International Journal of Humanities and Social Science, 4(3), 180-198.

Atolagbe, A. A. (2017). Donald Trump's alternative facts re-shaping national and international discourses: The

Big D analysis. Advances in Social Sciences Research Journal, 4(11), 119-126. https://doi.org/10.14738/assrj.411.3263

Babaee, M., Le, Q., \& Le, T. (2013). How are the concepts 'reliability' and 'validity' dealt with in qualitative research? In Q. Le \& T. Li (Eds.), Conducting research in a changing and challenging world (pp. 135-143): Nova Science Publishers.

Bashir, M., Afzal, M. T., \& Azeem, M. (2008). Reliability and validity of qualitative and operational research paradigm. Pakistan Journal of Statistics and Operation Research, 4(1), 35-45. http://dx.doi.org/10.18187/pjsor.v4i1.59

Cullen, J. (2017). The system is rigged; A discursive analysis of Donald Trump and Bernie Sanders. (Master's thesis), London School of Economics and Political Science. Retrieved from http://www.lse.ac.uk/media-and-communications/assets/documents/research/msc-dissertations/2016/Dis sertation-Jessica-Cullen.pdf

Erasga, D. S. (2012). Methodological promises of discourse analysis in Philippine environmental research. Pacific Asia Inquiry, 3(1), 116-131.

Fairclough, N. (1995). Critical discourse analysis: The critical study of language. London: Routledge.

Fairclough, N. (2013). Language and power ( $2^{\text {nd }}$ ed.). New York: Routledge.

Fowler, R., Hodge, B., Kress, G., \& Trew, T. (1979). Language and control. London: Routledge and Keganpaul.

Gramsci, A. (1971). Selections from the prison notebooks of Antonio Gramsci (Q. Hoare \& G. N. Smith, Trans. Q. Hoare \& G. N. Smith Eds.). New York: International Publishers.

Guba, E. G., \& Lincoln, Y. S. (1981). Effective evaluation: Improving the usefulness of evaluation results through responsive and naturalistic approaches. San Francisco, California: Jossey-Bass.

Halliday, M. A. (1971). Linguistic function and literary style: an inquiry into the language of William Goldinges The Inheritors. In J. J. Webster (Ed.), Linguistic studies of text and discourse (pp. 88-125). Peking: Peking University Press.

Jørgensen, M. W., \& Phillips, L. J. (2002). Discourse analysis as theory and method. London: Sage Publication. https://doi.org/10.4135/9781849208871

Kallia, A. (2005). Directness as a source of misunderstanding: The case of requests and suggestions. In R. T. Lakoff \& S. Ide (Eds.), Broadening the horizon of linguistic politeness (pp. 217-234). Amsterdam: John Benjamins. https://doi.org/10.1075/pbns.139.19kal

Khany, R., \& Hamzelou, Z. (2014). A systemic functional analysis of dictators' speech: Toward a move-based model. Procedia - Social and Behavioral Sciences, 98, 917-924. https://doi.org/10.1016/j.sbspro.2014.03.500

Landler, M., \& Sanger, D. E. (2017, October 13). Trump disavows nuclear deal, but doesn't scrap it. The New York Times. Retrieved from https://www.nytimes.com/2017/10/13/us/politics/trump-iran-nuclear-deal.html

Luke, A. (1997). Theory and practice in critical discourse analysis. International encyclopedia of the sociology of education, 8, 50-57. Retrieved from https://pages.gseis.ucla.edu/faculty/kellner/ed270/Luke/SAHA6.html

Martin, J. R., \& White, P. R. R. (2005). The language of evaluation. London: Palgrave Macmillan. https://doi.org/10.1057/9780230511910

Mazlum, F., \& Afshin, S. (2016). Evaluative language in political speeches: A case study of Iranian and American presidents' speeches. International Journal of Linguistics, 8(4), 166-183. https://doi.org/10.5296/ijl.v8i4.9398

Mcclay, R. (2017). Us and them: A descriptive analysis of Donald Trump's campaign speeches (Master's thesis), University of Birmingham. Retrieved from https://www.birmingham.ac.uk/Documents/college-artslaw/cels/essays/appliedlinguistics/McClay2017. Trump-Speech-Discourse-Analaysis.pdf 
Word War: A critical discourse analysis of the UN general assembly's annual debate, 2017

Mohammadi, M., \& Javadi, J. (2017). A critical discourse analysis of Donald Trump's language use in US presidential campaign, 2016. International Journal of Applied Linguistics and English Literature, 6(5), 1-10. https://doi.org/10.7575/aiac.ijalel.v.6n.5p.1

Rachman, A., \& Yunianti, S. (2017). Critical discourse analysis in Donald Trump presidential campaign to win American's heart. Universitas Muhammadiyah Surabaya TELL, 5(2), 8-17. Retrieved from http://journal.um-surabaya.ac.id/index.php/Tell/article/download/388/543

Regime. (n.d.). In Longman Dictionary of Contemporary English Online. Retrieved from https://www.ldoceonline.com/dictionary/regime

Remarks by President Trump on Iran Strategy. (2017, October 13). The White House National Security \& Defense. Retrieved from https://www.whitehouse.gov/briefings-statements/remarks-president-trump-iran-strategy/

Resolution 2231. (2015). The United Nations Security Council Retrieved from http://www.un.org/en/sc/2231/

Sahragard, R., \& Moghadam, M. (2015). Moving in a gyre: A discourse analysis of President Rouhani's de facto inaugural speech. Studies in English Language Teaching, 3(3), 237-251. http://dx.doi.org/10.22158/selt.v3n3p237

Sclafani, J. (2018). Talking Donald Trump: A sociolinguistic study of style, metadiscourse, and political identity. New York: Routledge.

Sharififar, M., \& Rahimi, E. (2015). Critical discourse analysis of political speeches: A case study of Obama's and Rouhani's speeches at UN. Theory and Practice in Language Studies, 5(2), 343-349. http://dx.doi.org/10.17507/tpls.0502.14

Shear, M. D. (2017, June 1). Trump will withdraw U.S. From Paris Climate Agreement. The New York Times Retrieved from https://www.nytimes.com/2017/06/01/climate/trump-paris-climate-agreement.html

Sipra, M. A., \& Rashid, A. (2013). Critical discourse analysis of Martin Luther King's speech in socio-political perspective. Advances in Language and Literary Studies, 4(1), 27-33. https://doi.org/10.7575/aiac.alls.v.4n.1p.27

Sriwimon, L., \& Zilli, P. J. (2017). Applying critical discourse analysis as a conceptual framework for investigating gender stereotypes in political media discourse. Kasetsart Journal of Social Sciences, 38(2), 136-142. https://doi.org/10.1016/j.kjss.2016.04.004

Statement by H.E. Dr. Hassan Rouhani: President of the Islamic Republic of Iran (PDF File). (2017). The United Nations. Retrieved from https://gadebate.un.org/sites/default/files/gastatements/72/ir_en.pdf

Statement by H.E. Mr. Donald Trump: President of the United States of America (PDF File). (2017). The United Nations. Retrieved from https://gadebate.un.org/sites/default/files/gastatements/72/us_en.pdf

Stenbacka, C. (2001). Qualitative research requires quality concepts of its own. Management Decision, 39(7), 551-556. https://doi.org/10.1108/EUM0000000005801

Strauss, A. L., \& Corbin, J. M. (1990). Basics of qualitative research: grounded theory procedures and techniques. Newbury Park, California: Sage Publications, Inc.

Sulistyo, B. A., \& Khristianto, K. (2017). Political discourse analysis on Trump's ideology. JSSH: Jurnal Sains Sosial dan Humaniora, 1(1). Retrieved from http://jurnalnasional.ump.ac.id/index.php/JSSH/article/download/1035/1209

Tsuzuki, M., Takahashi, K., Patschek, C., \& Zhang, Q. (2005). Selection of linguistic forms for requests and offers: Comparison between English and Chinese. In R. T. Lakoff \& S. Ide (Eds.), Broadening the Horizon of linguistic politeness (pp. 283-296). Philadelphia: John Benjamins. https://doi.org/10.1075/pbns.139.23tsu

Van Dijk, T. A. (2006). Ideology and discourse analysis. Journal of Political Ideologies, 11(2), 115-140. https://doi.org/10.1080/13569310600687908

Van Dijk, T. A. (2008a). Discourse and context: A sociocognitive approach. New York: Cambridge University Press. https://doi.org/10.1017/CBO9780511481499

Van Dijk, T. A. (2008b). Discourse and power. New York: Palgrave Macmillan. https://doi.org/10.1007/978-1-137-07299-3 
Rezvani Sichani, B., Rezvani, E., \& Moinzadeh, A.

Wang, J. (2010). A critical discourse analysis of Barack Obama's speeches. Journal of language teaching and research, 1(3), 254-261. https://doi.org/10.4304/jltr.1.3.254-261

Widdowson, H. (2004). Text, context, pretext: Critical issues in discourse analysis. Melbourne: Blackwell. https://doi.org/10.1002/9780470758427 